\title{
HABSBURG NA TRONIE ANGLII O POZYCJI FILIPA HABSBURGA W ANGLII W LATACH 1554-1558
}

\begin{abstract}
Streszczenie. Ślub Filipa Habsburga i Marii Tudor wywołał w Anglii liczne kontrowersje. Obawiano się, że małżeństwo królowej z Habsburgiem może stać się zagrożeniem dla angielskiej niezależności. Nie dziwią więc szczegółowe ustalenia dotyczące zakresu władzy Filipa zawarte $\mathrm{w}$ traktacie małżeńskim. Filip w trakcie swojego pobytu interesował się wewnętrznymi sprawami Anglii i angażował się w administrowanie krajem. Doprowadził również do uczestnictwa Anglii w wojnie z Francją, która doprowadziła do utraty Calais przez ojczyznę jego żony. Bezdzietna śmierć Marii sprawiła, że Habsburg utracił wszelkie wpływy w Anglii.
\end{abstract}

Słowa kluczowe: Filip Habsburg, Maria I, władza, Anglia.

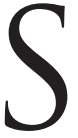

prawa małżeństwa władcy od wieków budzi emocje. W przypadku, kiedy monarchą zostaje kobieta, jej ślub odgrywa szczególną rolę. Gdy Maria Tudor w lipcu 1553 r. wstąpiła na tron Anglii, kwestia wyboru odpowiedniego małżonka dla niej, stała się sprawą państwową. Urodzona w 1516 r. królowa powoli wchodziła w wiek, w którym zajście w ciąże stawało się utrudnione. Dlatego też jej mariaż był istotny z punktu widzenia zapewnienia sukcesji w państwie. Od razu pojawiły się pytania o to, kto powinien zasiąść na tronie Albionu obok monarchini. Czy winien być to jej rodak czy też cudzoziemiec? Jaki powinien być zakres jego władzy? Na te pytania doradcy królowej z Tajnej Rady musieli znaleźć odpowiedzi, gdyż do tej pory w Albionie nie pojawiła się wcześniej osoba pełniące rolę króla-małżonka. Tymczasem pozycja mężatki w Anglii pod względem prawnym znacznie ograniczała możliwości działania kobiety. Wdowy mogły samodzielnie sprawować opiekę nad dziećmi, prowadzić interesy czy też występować w sądzie w charakterze 
powoda, jednak zamężne niewiasty nie miały takich możliwości. Żona, chociaż mogła przed instytucjami reprezentować swego męża, to sama bez jego zgody, nie mogła wnieść powództwa ${ }^{1}$. Należy więc zadać sobie pytanie, jaką w takim razie pozycję w ojczyźnie Marii I zajmował jej mąż. Z jednej strony jego pozycję kształtowały akty prawne, takie jak umowa małżeństwa, z drugiej jednak codzienna praktyka. W niniejszym artykule postaram się znaleźć odpowiedź na pytanie, jak kształtowała się prawna pozycja małżonka królowej Anglii, a także czy różniła się od tej, którą zajmował w praktyce. Będę starała się przyjrzeć temu, czy Filip Habsburg pragnął wypełniać obowiązki przewidziane dla króla Albionu, czy też nie chciał mieszać się do polityki w tym kraju.

Od początku panowania Marii było jasne, że władczyni męża będzie szukać w rodzie Habsburgów. Córka Henryka VIII utrzymywała od czasów swej młodości bliskie kontakty z siostrzeńcem matki - cesarzem Karolem V. W czasach panowania Edwarda VI przedstawiciele rodu austriackiego otwarcie występowali w obronie jej praw, szczególnie naciskając na to, by królewna mogła pozostać przy wyznaniu katolickim. Karol V spodziewał się, że świeżo upieczona królowa może chcieć poślubić właśnie jego. Ze względu na swój stan zdrowia i wiek Habsburg uważał to za niemożliwe. Polecał jednak jako kandydata do ręki kuzynki swego syna Filipa². Biskup Arras - Antoine Perrenot de Granvelle nakazał Simonowi Renardowi ${ }^{3}$ dowiedzieć się, jak sama Maria zapatruje się na ten związek. Dyplomata stwierdził w odpowiedzi, że królowa nie jest przekonana do małżeństwa z Anglikiem, albowiem w razie wystąpienia jakiś niepokojów, nie będzie mogła oprzeć się na sile reprezentowanej przez jej męża. Obcokrajowiec zaś mógłby ją chronić i udzielać wsparcia w razie problemów. Jednocześnie Marii na myśl nie przyszło małżeństwo z księciem Filipem, albowiem wiedziała o planach jego związku z portugalską księżniczką. Dlatego też Renard zauważył w rozmowie z Tudorówną, że sprawa ta nie jest ustalona, sugerując tym samym, iż młody Habsburg może poślubić właśnie władczynię Albionu4. Na giełdzie kandydatów do ręki władczyni pojawiało się z upływem kolejnych miesięcy coraz więcej kandydatów do ręki królowej. Wśród rodaków córki Henryka VIII najczę-

${ }^{1}$ P. Hogrefe, Legal Rights of Tudor Women and the Circumvention by Men and Women, „The Sixteenth Century Journal" 1972, vol. 3, no. 1, s. 97-100.

2 Karol V do księcia Filipa, 30 lipca 1553, Calendar of State Papers, Spain (dalej: CSP, Spain), red. M. Hume, R. Tyler, London 1916, vol. 11, s. 126-127.

3 Simon Renard przybył do Anglii pod koniec panowania Edwarda VI. Współpracował jako wysłannik Habsburgów z ówczesnym ambasadorem na dworze Tudora - Jehanem Scheyfve. Po wstąpieniu na tron Marii stał się wpływową osobą w jej otoczeniu, z którą władczyni często konsultowała najważniejsze decyzje.

${ }^{4}$ Simon Renard do biskupa Arras, 7 sierpnia 1553, CSP, Spain, s. 152-153. 
ściej wymieniano hrabiego Devon, czy też kardynała Richarda Pole’a. Wśród cudzoziemców zaś coraz częściej wspominano o arcyksięciu Ferdynandzie, którego portret, ku niezadowoleniu Renarda, przywiózł ze sobą ambasador króla rzymskiego - Guzman ${ }^{5}$. Ambasador Karola robił więc wszystko, aby serce królowej Mari szybciej biło na myśl o innym Habsburgu - synu jego pana. Kim był więc kandydat do ręki angielskiej władczyni?

Filip urodził 21 maja 1527 r. w Valladoid. Do siódmego roku za jego wychowanie odpowiadała matka - cesarzowa Izabela, która niezbyt przejmowała się zapewnieniem formalnej edukacji dziecku. Infant spędził więc pierwsze lata beztrosko na hiszpańskim dworze, pełnym kobiet oczekujących na swych mężów, którzy opuścili kraj razem ze swym królem. Dopiero powrót Karola $V$ na półwysep iberyjski pociągnął za sobą początek edukacji księcia. Już 1 czerwca 1534 r. na nauczyciela Filipa wyznaczono Juana Martineza Saliceo, który jednak zdaniem cesarza, zbytnio pobłażał jego synowi ${ }^{6}$. Arcyksięciu zorganizowano także osobny dwór, którym zarządzał Juan de Zuniga. Szczęśliwe dzieciństwo Filipa przerwała śmierć matki, która zmarła w 1539 r. Całość wychowania dwunastoletniego syna przejął wówczas Karol V i zaczął wdrażać syna w system rządów nad Kastylią i Aragonią7.

W latach 40. cesarz zaczął poszukiwania najlepszej kandydatki na żonę dla potomka. Filip 15 listopada 1543 r. poślubił córkę portugalskiego króla - Marię Manuelę. Rok po ślubie Maria zaszła w ciążę, która zakończyła się 8 lipca 1545 r. narodzinami syna - Karola. Niestety już trzy dni później królewna zmarła w wyniku komplikacji poporodowych. Od tej pory Filip po raz kolejny stał się pionkiem na habsburskiej szachownicy małżeństw dynastycznych ${ }^{8}$.

Renard starał się przekonać Marię, że Filip jest dla niej najodpowiedniejszym kandydatem na męża. Zachwalał wiek księcia, który miał być optymalny do zawarcia małżeństwa. Co więcej zaletą syna Karola $\mathrm{V}$ było też to, że ma już kilkuletniego syna'. Zdaniem Renarda najlepszą drogą do małżeństwa będą oficjalne rozmowy z uwzględnieniem Tajnej Rady. Ambasador był zdania, że spośród jej członków najbardziej przychylnie nastawiony do zagranicznego małżeństwa jest William Paget. Poza księciem Filipem, według wysłannika Habsburgów jako kandydata do ręki Marii rozważano chociażby

\footnotetext{
${ }^{5}$ M.M. de Courrières, de Thoulouse, Simon Renard, Jehan Scheyfve do Karola V, 4 sierpnia 1553 CSP, Spain, s. 203-204.

${ }^{6}$ Kiedy Karol V dowiedział się, że Saliceo został spowiednikiem Filipa powiedział: „Mam nadzieję, że nie będzie pobłażał ci tak bardzo w sprawach sumienia, jak pobłażał ci w sprawach studiów", G. Parker, Filip II, Warszawa 1985, s. 14.

${ }^{7}$ H. Kelsey, Philip of Spain. King of England: the forgottensovereign, London 2012, s. 15-17.

${ }^{8}$ L. Pfandl, Philipp II. - Gemäldeeines Lebensundeiner Zeit, Hamburg 2013, s. 82-88.

${ }^{9}$ Simon Renard do biskupa Arras, 8 września 1553, CSP, Spain, s. 213-215.
} 
księcia Sabaudii ${ }^{10}$. 0 królowej Marii przypomniał sobie także książę Portugalii rozważany jako narzeczony władczyni już za panowania Edwarda VI. Jego też do konkurów zniechęcał Karol V ${ }^{11}$. Największą sympatią członków Rady cieszyła się jednak kandydatura Edwarda Courtenay hrabiego Devonshire. Jego główną zaletą było to, że był Anglikiem, a co więcej ostatnim potomkiem Yorków. Był bowiem prawnukiem Edwarda IV a jego ojciec został ścięty w 1538 r. pod zarzutem zdrady stanu. Samego Edwarda, zaledwie dziesięcioletniego, uwięziono w Tower. Za murami londyńskiej twierdzy spędził 27 lat, uwolniono go dopiero 3 sierpnia 1553 r. na polecenie Marii ${ }^{12}$. Długoletnie uwięzienie nie pozostało bez wpływu na jego psychikę, z czego doskonale zdawała sobie sprawę sama królowa. Mimo to jego kandydaturę popierał chociażby William Rochester, dążący do ograniczenia wpływu Habsburgów na Anglię ${ }^{13}$. Także parlament chętniej widziałby u boku królowej Anglika.

Sama władczyni nie wiedziała na którego kandydata powinna się zdecydować. Pragnęła poślubić księcia Filipa, lecz widziała opór, jaki ta kandydatura budzi u jej doradcach. Ambasadorowi Renardowi urządzała histeryczne wręcz sceny, które doświadczony dyplomata cierpliwie znosił ${ }^{14}$. Żeby dodatkowo zachęcić Marię do kandydatury Filipa Habsburgowie chcieli wysłać jej portret księcia autorstwa Tycjana, który przedstawicieli dynastii austriackiej potrafił malować w wyjątkowo korzystny dla nich sposób. Anglicy tymczasem mieli wiele obaw związanych z ewentualnym ślubem ich władczyni z Habsburgiem. Szczególnie niepokoiło ich to, czy związek ten nie spowoduje konfliktu zbrojnego z Francją. Ponadto nie podobał im się fakt, że kandydat na króla nie władza językiem angielskim. Tę wątpliwość Renard zbywał, twierdząc, że Filip zna francuski i łacinę, więc bez problemu nauczy się kolejnego języka ${ }^{15}$.

Sojusznikiem domu austriackiego był William Paget, który jeszcze w czasach Edwarda VI utrzymywał dobre stosunki z Habsburgami. Otwarcie agitował on za małżeństwem Marii z Filipem i niejednokrotnie rozmawiał na ten temat z Renardem. Karol V starał się zaś przekonać zwolenników angielskiego małżeństwa Marii, na czele z Gardinerem, Rochesterem, Englefieldem i Waldegravem, wysyłając do nich listy. Przeciwnicy małżeństwa z Habsburgiem wysuwali najróżniejsze obiekcje. Szczególnie niepokoiła ich możliwa utrata niezależności przez Anglię, a także obawa o reakcję Francji za związek

${ }^{10}$ Simon Renard do Karola V, 5 października 1553, CSP, Spain, s. 265.

11 Karol V do Simona Renarda, 21 sierpnia 1553, CSP, Spain, s. 378-380.

12 J. Taylor, The shadow of the whiterose. Edward Courtenayearl of Devon. 1526-1556, New York 2006, s. 121.

13 L. Porter, Maria Tudor, Kraków 2010, s. 311.

14 Simon Renard do Karola V, 31 października 1553, CSP, Spain, s. 329-331.

15 Simon Renard do Karola V, 6 listopada 1553, CSP, Spain, s. 337-342. 
królowej Albionu z największym wrogiem Henryka II. Ponadto dopytywali się o to, w jaki sposób zostanie podzielona władza nad imperium Habsburgów i które terytoria mają przypaść w udziale Filipowi, a które bratu cesarza.

W końcu Karol V zdecydował się ostatecznie rozwiać wątpliwości doradców Marii. 25 listopada wystosował do członków Tajnej Rady pismo, w którym przedstawiał szczegóły propozycji małżeństwa między jego synem a władczynią Anglii. Cesarz obiecywał, że jeżeli Filip doczeka się potomstwa z tego związku wówczas obejmie ono władzę nie tylko w Anglii, ale także w Niderlandach. Terytoria hiszpańskie i włoskie miał odziedziczyć jego wnuk z pierwszego małżeństwa ${ }^{16}$. $\mathrm{W}$ tej propozycji widać, z jaką powagą Karol planował angielskie małżeństwo i jakie były jego oczekiwania odnośnie do tego związku. Cesarz liczył bowiem, że mariaż Filipa zapoczątkuje trzecią linię Habsburgów ${ }^{17}$. W związku z tym Karol zwracał uwagę na najdrobniejsze szczegóły w negocjacjach z Anglią. Zdając sobie sprawę z wagi polityki dynastycznej naciskał, aby w traktacie małżeński znalazły się szczegółowe rozporządzenia dotyczące tego, kto będzie miał wpływ na wybór męża dla ewentualnej córki narodzonej z planowanego związku, w przypadku śmierci jej ojca ${ }^{18}$. Sam książę do pomysłu ojca nie podszedł z entuzjazmem. Nie uśmiechało mu się poślubienie znacznie starszej od siebie królowej Albionu, zwłaszcza, że do tej pory prowadził negocjacje w sprawie małżeństwa z księżniczką portugalską Marią, która oprócz młodego wieku i urody mogła poszczycić się także wysokim posagiem ${ }^{19}$.

${ }^{16}$ A Proposal to be made by the Emperor to the principal lords and members of the Council of State, 25 listopada 1553, CSP, Spain, s. 387.

17 F. Kubiaczyk, Cesarz Karol V. Klęska polityki, triumf idei, Oświęcim 2017, s. 133-134.

18 Karolowi zależało, aby wpływ na wybór męża dla hipotetycznej córki Filipa i Marii miał wnuk cesarza don Carlos. Habsburg uzasadniał to tym, że królewna będzie nie tylko spadkobierczynią Anglii i Niderlandów, ale także może kiedyś stać się dziedziczką Hiszpanii, dlatego też tak ważne jest, aby władca tego kraju miał wpływ na związek swej siostry; Karol V do Simona Renarda, 28 listopada 1553, s. 387-390.

${ }^{19}$ Maria (1521-1577) była jedynym dzieckiem króla Manuela i siostry Karola V Eleonory. Jej brat oferował Filipowi posag w wysokości 200 tysięcy dukatów. Związek ten był negocjowany przez wiele miesięcy i jeszcze przed dojściem Marii Tudor do władzy był przedmiotem konfliktu między cesarzem i jego synem. Karol V planował bowiem, że syn Filipa z pierwszego małżeństwa odziedziczy jedynie terytoria hiszpańskie, zaś dziecko księcia z księżniczką portugalską odziedziczy Niderlandy, w których się wychowa. Tymczasem Filip chciał po ślubie pozostawić żonę w Hiszpanii, gdzie sprawowałaby władzę, samemu udając się do Niderlandów, aby dopilnować tam przejęcia władzy. Do tego król Portugalii Jan III, widząc, że Habsburgowi zależy na związku z jego przyrodnią siostrą, chciał obniżyć wysokość posagu, co spotkało się z gwałtownym sprzeciwem domu austriackiego i kolejnymi negocjacjami na temat wysokości posagu portugalskiej księżniczki, które ostatecznie do niczego nie doprowadził. Sprawę komplikował także pomysł Karola, aby negocjacje małżeńskie prowadziła matka Marii, starsza siostra cesarza - Eleonora. Ostatecznie portugalska księżniczka nigdy nie stanęła na ślubnym 
Mimo to na początku grudnia 1553 r. Filip udzielił pełnomocnictwa hrabiemu d'Egmont, hrabiemu de Lalaing, M. de Courrières i Philip Nigri, kanclerzowi orderu złotego runa do prowadzenia w jego imieniu pertraktacji małżeńskich z Marią i zawarcia z królową Anglii związku per verba de preasenti. Habsburg zaznaczał, że zaakceptuje wszystkie warunku ustalone przez jego wysłanników ${ }^{20}$. Mimo daleko posuniętych negocjacji, Anglicy wciąż niepokoili się, że małżeństwo ich królowej z hiszpańskim księcia wplącze Albion w konflikt z Francją. Obawy te podsycał francuski ambasador. Także w społeczeństwie angielskim zaczęto wyrażać sprzeciw wobec hiszpańskiego związku władczyni z Filipem. Mówiono, że faktyczna władza będzie w rękach Hiszpanów, a także zaczęto wypominać Marii, że w jej żyłach płynie hiszpańska krew ${ }^{21}$. Ponadto Gardiner podnosił argumenty natury ekonomicznej, obawiając się, że małżeństwo spowoduje otwarcie angielskiego rynku dla hiszpańskich kupców, co osłabi pozycję miejscowych przedsiębiorców. Renard starał się go przekonywać, że większa konkurencja nie zaszkodzi Anglikom, a wręcz przeciwnie pobudzi handel ${ }^{22}$.

Niechęć do mieszkańców półwyspu iberyjskiego była w Albionie głęboko zakorzeniona. W publikacjach skierowanych przeciwko Hiszpanom przypominano o ich ofensywnej polityce w Italii. Anglicy obawiali się imperialnej polityki Kastylii i Aragonii ${ }^{23}$. Ponadto angielscy protestanci widzieli w katolickich Hiszpanach zarazę zesłaną przez Boga ${ }^{24}$.

Mimo wszystkich przeciwności negocjacje małżeńskie toczyły się intensywnie. Karol V chciał, aby Filip udał się do Anglii jak najszybciej po dopięciu na ostatni guzik negocjacji ${ }^{25}$. Ostatecznie zakończono je w styczniu 1554 r., kiedy to powstała końcowa wersja traktatu małżeńskiego.

W dokumencie już na samym początku zaznaczono, że Filip będzie miał prawo do wszystkich tytułów, jakie przysługują jego żonie, jednak tylko na czas ich małżeństwa. Habsburg zobowiązywał się do przestrzegania

kobiercu. Poświęciła się za to sprawom duchowym oraz zasłynęła jako patronka artystów; M.J. Rodríguez-Salgado, The Changing Face of Empire: Charles V, Philip II and Habsburg Authority, 1551-1559, Cambridge 1988, s. 77-80.

${ }^{20}$ Pełnomocnictwo udzielone przez Filipa, grudzień 1553, CSP, Spain, s. 407.

21 Simon Renard do Karola V, 3 grudnia 1553, CSP Spain, s. 410-415.

${ }^{22}$ J. Edwards, Mary I: England's Catholic Queen, Yale 2011, s. 154.

${ }^{23}$ A. Samson, The marriage of Philip of Habsburg and Mary Tudor and anti-Spanish sentiment in England: politicaleconomies and culture, 1553-1557, London 1999, s. 74-76 (rozprawa doktorska przygotowana na University of London), https://qmro.qmul.ac.uk/xmlui/ handle/123456789/1604, dostęp: 18.05.2018.

${ }^{24}$ M. Sanchez, Anti-Spanish sentiment in English literary and politicalwriting 1553-1603, Leed 2004, s. 45 (rozprawa doktorska), http://etheses.whiterose.ac.uk/392/1/uk_bl_ethos_ 414874.pdf, dostęp: 18.05.2018.

${ }^{25}$ Karol V do Simona Renarda, 15 grudnia 1553, CSP, Spain, s. 430. 
wszystkich praw i obyczajów królestwa, do którego przybywał. Miał wraz z królową zarządzać państwem, jednak zrzekał się prawa do nadawania urzędów i beneficjów, pozostawiając tę kwestię żonie. Ponadto w traktacie wyraźnie zaznaczono, że wszelkie dokumenty będą publikowane w miejscowym języku. Jednocześnie w traktacie podkreślono fakt, że Maria dzieli się należną jej władzą z mężem ${ }^{26}$.

Szczegółowe ustalenia dotyczące przynależnej Filipowi władzy były konieczne ze względu na nietypowość sytuacji, jaka wiązała się z małżeństwem Marii. Po raz pierwszy do Anglii miał przybyć zagraniczny książę, aby poślubić panującą władczynię. Obawiano się więc tego, że zdominuje żonę i będzie sprawował władzę w jej imieniu. Dodatkowo przybywający królewski małżonek pochodził z rodu Habsburgów, który, jak określił to Dawid Loades, prowadził politykę podboju przez małżeństwo. Dlatego też członkom angielskiej Tajnej Rady zależało na podkreśleniu suwerenności Anglii. W związku z nieznaną wcześniej sytuacją wszystkie rozwiązania na bieżącą proponował dyplomata Karola $\mathrm{V}^{27}$. Jednocześnie jednak formalnie uznano prawo Filipa do dzierżenia władzy w Albionie. W przeciwieństwie do przybywających do mężów księżniczek z obcych dynastii, Habsburgowi przyszła małżonka zapewniała małżonkowi udział w sprawowaniu władzy. Jednocześnie wszelkie jego kompetencje miały ustać w chwili śmierci królowej.

Szczegółowo ustalono także zasady dziedziczenia tronu ewentualnych dzieci narodzonych z zawieranego małżeństwa. Potomek Filipa i Marii, niezależnie od płci, miał prawo do dziedziczenia królestwa Anglii. Jednocześnie władza w hiszpańskich terytoriach Habsburgów, Sycylii i Mediolanie miała przypaść synowi Habsburga z pierwszego małżeństwa Karolowi i jego potomkom. Dopiero w razie wygaśnięcie ich linii władzę w Hiszpanii mieli przejąć potomkowie Marii. Dodatkowo, jeżeli jedynym dzieckiem byłaby córka, wówczas miała ona przejąć władzę w Niderlandach. W kwestii wyboru swego męża, musiałaby jednak skonsultować się ze swym przyrodnim bratem, gdyby zaś bez jego zgody wyszła za osobę nie będącą ani mieszkańcem Niderlandów ani Anglikiem, władza we Flandrii miała wrócić do linii syna Filipa. Dodatkowo traktat zapowiadał ścisłą współpracę Anglii z Cesarzem i wszelkimi ziemiami, jakie znajdowały się pod jego panowaniem ${ }^{28}$.

Wynegocjowane warunki traktatu małżeńskiego rozsierdziły Filipa, który poczuł się oszukany. Karol V obiecywał mu, że zostanie królem Anglii,

${ }^{26}$ Act for the Marriage of Queen Mary to Philip of Spain, [w:] Select Documents of English Constitutional History, red. G. Adams, H. Stephens, London 1920, s 281-184.

27 D. Loades, Philip II and the goverment of England, [w:] Law and govermentuder the Tudors, red. Claire Cross, D.M. Loades, J.J. Scarisbrick, Cambridge 1988, s. 177-178.

${ }^{28}$ Act for the Marriage..., s. 184. 
tymczasem w rzeczywistości jego kompetencje ściśle reglamentowano. Książę miał poczucie, że negocjatorzy ojca nie podołali postawionemu przed nimi zadaniu ${ }^{29}$. Podpisał więc dokument, w którym oświadczał, że nie poczuwa się do przestrzegania tych artykułów, które obciążałyby jego sumienie. Habsburg nie czuł się także zobowiązany ratyfikowanym traktatem, gdyż udzielił pełnomocnictwa jedynie do zawarcia w jego imieniu traktatu małżeńskiego, nie zaś podejmowania decyzji, które wiązałyby nie tylko jego, ale także potomków Filipa ${ }^{30}$. Swojego niezadowolenia książę nie śmiał jednak okazać ojcu, którego zapewniał o radości, jaką odczuwa z powodu pomyślnego zakończenia negocjacji oraz informowało o planach ubiegania się o dyspensę od papieża ${ }^{31}$. Sam cesarz zapewniał go, że Maria zapewniła jego dyplomatów, iż będzie spełniała wszystkie życzenia męża, w co Karol V wierzył ${ }^{32}$.

Wybór Habsburga na króla Anglii wywołał nową falę niezadowolenia. Tym razem nie ograniczyła się ona jedynie do publikacji anonimowych pamfletów, lecz pociągnęła za sobą zbrojne powstanie. Wydarzenie związane z tak zwaną rebelią Wyatta nie zdołały jednak doprowadzić do wycofania się z negocjacji. Powstańców szybko pokonano, zaś ich przywódców przykładnie ukarano ${ }^{33}$. Po zduszeniu oporu, nic już nie stało na drodze do zawarcia małżeństwa między królową a Habsburgiem. Już 6 marca odbyły się oficjalne zaręczyny. Maria nie posiadała się z radości, że po wielu latach oczekiwania na ślub i tak wielu zrywanych obietnicach małżeńskich, wreszcie stanie na ślubnym kobiercu. Wypytywała Renarda o szczegóły z życia męża i wyrażała chęć jak najszybszego spotkania się z Filipem. Tymczasem w kwietniu parlament ratyfikował wcześniej wynegocjowany układ małżeński. Ponadto, aby rozwiać wszelkie wątpliwości dotyczące pozycji Marii przegłosowano dokument, w którym podkreślano suwerenną władzę królowej. To do niej i do nikogo innego, zgodnie z prawem należała pełnia władzy nad krajem. Zaznaczono także, że płeć królowej nie wpływa na zakres jej kompetencji, dzierży te same uprawnienia, jakie na jej miejscy przysługiwałyby królowi mężczyźnie ${ }^{34}$. Anglicy poprzez prawne podkreślenie prerogatyw władczyni, chcieli zapobiec zdominowaniu królowej przez męża ${ }^{35}$. Tym samym Filip nie

29 L. Porter, op. cit., s. 350-351.

${ }^{30}$ A writing ad cautelam, drawn up on account of this capitulation, CSP, Spain, vol. 12, s. 3-4.

${ }^{31}$ Filip Habsburg do Karola V, 6 stycznia 1554, CSP, Spain, s. 8-10.

32 Karol V do Filipa Habsburga, 21 stycznia 1554, CSP, Spain, s. 36-37.

${ }^{33}$ Vide: E.Simson, The Queen and the Rebel. Mary Tudor and Thomas the Younger, London 1964

${ }^{34}$ An Acte declaring that the Regall Power of this Realm is in the Quenes Mary as fully and absolutely as everit was in any of hermoste noble Progenitours Kingf of this Realme, [w:] The statutes of the realm, vol. 3, part. 1, London 1819, s. 222.

35 A. Samson, op. cit., s. 174-175. 
mógł oczekiwać, że uda mu się przejąć pełnię władzy w Albionie i zastąpić małżonkę w wykonywaniu jej obowiązków.

Już 12 czerwca młody Habsburg oficjalnie rozpoczął podróż do Anglii. Wcześniej jednak swą regentką w Hiszpanii ustanowił siostrę Joannę ${ }^{36}$ oraz pożegnał się z synem. W końcu 25 czerwca opuścił Hiszpanię ${ }^{37}$. Pewną osłodę w sytuacji niechętnie zawieranego małżeństwa mogło stanowić to, że w prezencie od ojca otrzymał tytuł króla Neapolu oraz księcia Mediolanu ${ }^{38}$. Dzięki temu w chwili ślubu mógł się, tak jak przyszła małżonka, poszczycić królewskim tytułem, co mogło mieć znaczenie w oficjalnych sytuacjach. Także w Anglii już czerwcu rozpoczęły się przygotowania do przybycia księcia. Tajna Rada poleciła niejakiemu Williamsowi zorganizowanie służących dla Habsburga ${ }^{39}$.

Filip podróż do kraju narzeczonej przybył 12 lipca. Do Albionu udawał się w eskorcie 80 okrętów, które poza dodaniem arcyksięciu prestiżu miały zapewnić mu także bezpieczeństwo w razie problemów z Francją. Pierwsze spotkanie przyszłych małżonków miało miejsce 23 lipca w Winchesterze. Maria ubrana była w czarną, jedwabną suknię. Strój dopełniał bogaty komplet biżuterii. Królowej towarzyszyło wiele dworzan i dam dworu. Filip rozmawiał z władczynią Albionu mówiąc po Hiszpańsku, Tudorówna odpowiadała mu po francusku, oboje jednak doskonale się rozumieli. Maria zaczęła nawet uczyć przyszłego męża angielskiego i pod koniec dnia Filip potrafił już mieszkańcom Anglii życzyć „dobrej nocy” w ich rodzimym języku. Jeszcze przed ślubem przyszły król spotkał się z członkami Tajnej Rady, którzy przysięgli mu wierność jako królowi. Habsburg w odpowiedzi stwierdził, że przybył do Anglii, aby wypełnić wolę Boga, który chciał, żeby poślubił Marię. Dodał też, że do Albionu nie przybył, jako hiszpański ksiq̨żę czy obcy, ale jako Anglik. Zapewnił przyszłych poddanych o swojej miłości i chęci bycia dla nich jak najlepszym władcą ${ }^{40}$. Nieco mniej życzliwości okazywali Anglikom przybyli z Filipem Hiszpanie, którzy na każdym kroku krytykowali tubylców, którzy nie pozostawali dłużni w okazywaniu przybyłym pogardy ${ }^{41}$.

${ }^{36}$ Joanna (1535-1573) była drugim dzieckiem Karola V i jego żony Izabeli. W 1552 r. poślubiła następcę tronu Portugalii Jana Manuela. Jej mąż zmarł jednak już 2 stycznia $1554 \mathrm{r}$. na gruźlicę. 20 stycznia 1554 Joanna urodziła syna Manuela, który odziedziczył tron Portugalii; C. von Wurzbach, Habsburg, Johanna von Oesterreich (Gemalin Johann's), [w:] Biographisches Lexikon des Kaiserthums Oesterreich, Teil 6, Wien 1860, s. 290.

37 H. Kelsey, op. cit., s. 72-73.

38 Ibidem, s. 77.

${ }^{39}$ Acts of the Privy Council of England (dalej APC), red. J. Roche, vol. 5, London 1896, s. 31.

${ }^{40}$ H. Kelsey, op. cit., s. 80-83.

${ }^{41}$ J. Boyden, The Courtier and the King. Ruy Gómez De Silva, Philip II, and the Court of Spain, California 1995, s. 40-42. 
Długo oczekiwana przez Marię ceremonia ślubna odbyła się 25 lipca w Winchesterze. Na tę okazję świątynię przyozdobiono arrasami i złotymi tkaninami. Miejsce, w którym mieli usiąść narzeczeni przyozdobiono purpurą, Maria zasiadła po prawej stronie od ołtarza, Filip zaś po mniej prestiżowej - lewej, co w relacjach kastylijskich usprawiedliwiano tym, że Habsburg nie był koronowany ${ }^{42}$. Pan młody do świątyni przybył około godziny dziesiątej. Wkroczył do niej w otoczeniu grandów, którzy razem z nim przybyli do Albionu. Pół godziny później w otoczeniu członków Tajnej Rady oraz arystokratów do kościoła wkroczyła Maria ubrana w wysadzaną perłami purpurową suknię.

Ceremonię poprowadził biskup Gardiner, który nim przeszedł do wysłuchania przysięgi małżeńskiej poinformował zgromadzonych o warunkach traktatu małżeńskiego oraz jego ratyfikacji. Formułę ślubną wygłosili po łacinie i po angielsku, następnie wymienili się pierścieniami. Królowa od markiza Winchester oraz hrabiów Derby, Bedford i Pembroke otrzymała ślubne podarki. Już jako mąż i żona Filip wraz z Marią wysłuchali mszy świętej. Następnie heroldowie ogłosili nową tytulaturę małżonków, która od tej pory miała brzmieć:

Filip i Maria, z łaski Boga król i królowa Anglii, Francji, Neapolu, Jerozolimy i Irlandii, obrońcy wiary, książę i księżna Hiszpanii i Sycylii, arcyksiążę i arcyksiężna Austrii, książę i księżna Mediolanu, Burgundii i Brabancji, hrabia i hrabina Habsburga, Flandrii i Tyrolu ${ }^{43}$.

Z kościoła para królewska wraz z gośćmi przeniosła się do pałacu biskupa Gardinera, gdzie odbyła się uczta weselna. Oprócz smacznych posiłków nie zabrakło tańców, podczas których angielskie damy towarzyszyły hiszpańskim grandom. Po pewnym czasie Maria i Filip opuścili przyjęcie i zjedli osobno kolację. Później udali się do pobłogosławionej przez Gardinera sypialni. Następnego ranka rozpoczęło się codzienne życie małżonków. Wielu, a zwłaszcza Karol V, z małżeństwem królowej Anglii i Habsburga wiązało duże nadzieje, przyszłość jednak miała pokazać, że nie przyniosło ono spodziewanych profitów. Ślub Marii i Filipa, chociaż podkreślał większe znaczenie królowej, to jednocześnie podkreślał pozycję syna Karola V jako króla Anglii. Szczególnie istotne i symboliczne jest tu wymienienie właśnie jego imienia na początku długiej listy tytułów pary królewskiej. Po zawarciu małżeństwa Filip przestał być jedynie zagranicznym księciem, stał się monarchą. Tylko od niego miało teraz zależeć, na ile będzie to jedynie pusty tytuł.

42 A. Samson, Changing Places: The Marriage and Royal Entry of Philip, Prince of Austria, and Mary Tudor, July-August 1554, „The Sixteenth Century Journal” 2005, vol. 36, no. 3, s. 761-762.

${ }_{43}$ The chronicle of Jane Grey..., s. 167-168. 
Król Anglii wiedział, że musi zdobyć szacunek żony oraz nowych poddanych. Dlatego w pierwszych tygodnia małżeństwa traktował swą żonę jak najlepiej. Otaczał ją szacunkiem, publicznie okazywał miłość. Udało mu się także zdobyć sympatię doradców małżonki, do których odnosił się z odpowiednią dozą szacunku i bez wyniosłości ${ }^{44}$. Jednocześnie jednak Filip tuż po przybyciu do Anglii musiał się zmierzyć z niebagatelnym problemem finansowym. Jak się okazało bowiem Anglicy przygotowali dla niego dwór złożony z miejscowych, tymczasem Habsburg przybył z półwyspu Iberyjskiego razem ze wszystkimi niezbędnymi urzędnikami i służącymi. Od króla oczekiwano także, że sam będzie opłacał oba dwory. Dlatego też Filip musiał poradzić sobie z utrzymaniem 1000 Hiszpanów i 300 Anglików $^{45}$.

Anglicy liczyli na jak najszybsze korzyści ze związku swej pani z Habsburgiem. Dlatego też członkowie Tajnej Rady zwrócili się do Filipa z prośbą o wyrażenie zgody na wywóz z Hiszpanii 100 tysięcy dukatów, czego wcześniej odmówiła córka Karola V. Król Anglii odparł jednak, że nie jest w stanie nic zrobić, gdyż władzę w Kastylii i Aragonii pozostawił w rękach siostry Joanny i on sam ma obecnie związane ręce. Sprawę tę rozwiązał dopiero cesarz, który wyraził zgodę na przewiezienie wskazanej sumy pieniędzy do Anglii, lecz zaznaczył, że wywołało to duże niezadowolenie w Aragonii, więc podobna sytuacja nie może się już powtórzyćc ${ }^{46}$. Habsburg zdawał sobie sprawę z tego, że najlepiej sprawy angielskie rozumieją sami Anglicy, dlatego też chętnie korzystał z rad angielskich lordów, a zwłaszcza wieloletniego sprzymierzeńca domu austriackiego - Williama Pageta. To prawdopodobnie on doradził młodemu władcy okazywanie względów królewnie Elżbiecie ${ }^{47}$. Jednocześnie bliskie relacje króla z Pagetem wplątały go w konflikt, jaki angielski wielmoża toczył już od wielu miesięcy z kanclerzem Gardinerem, którego to niezmiennie popierała z kolei królowa ${ }^{48}$.

W początkach swojej bytności w Anglii Filip angażował się w sprawy wewnętrzne kraju. Dzięki jego staraniom Tower opuścili przedstawiciele rodu Dudley'ów, którzy przebywali w więzieniu od wydarzeń z lipca $1553 \mathrm{r}^{49}$ Wdzięczność z tego powodu w swym testamencie wyrażała wdowa po księciu Northumberland ${ }^{50}$. Ponadto syn cesarza starał się zdobyć przychylność

${ }^{44}$ Ruy Gómez de Silva do Francisca de Eraso, 12 sierpnia 1554, CSP, Spain, vol. 13, s. 27.

45 G. Redworth, Philip I of England, Embezzlement, and the Quantity Theory of Money, „The Economic History Review" 2002, vol. 55, no. 2, s. 257.

${ }^{46}$ Karol V do Simona Renarda, 2 września 1554, CSP, Spain, s. 40-41.

47 S. Gammon, Statesman and Schemer. William, First Lord Paget Tudor Minister, Newton Abbot 1973, s. 215.

${ }^{48}$ J. Edwards, op. cit., s. 208.

${ }^{49}$ D. Loades, Philip II and the..., s. 181-182.

50 R. McCoy, From the Tower to the Tiltyard: Robert Dudley's Return to Glory, „Historical Journal" 1984, vol. 27, no. 2, s. 425. 
lordów hojnie rozdając duże sumy pieniędzy ${ }^{51}$. Mimo wysiłków Filipa dochodziło do konfliktów między Hiszpanami towarzyszącymi królowi, a jego nowymi poddanymi. Jedną z przyczyn nieporozumień była bariera językowa, Anglicy nie znali hiszpańskiego, zaś przybyli z Habsburgiem nie władali angielskim. Dlatego też król starał się organizować zabawy, w których mogłyby uczestniczyć obie nacje, co pozwoliłby im na lepsze poznanie się ${ }^{52}$.

Dość szybko pojawiły się plotki dotyczące tego, że królowa jest w ciąży. Wieści te ucieszyły cesarza, jego siostrę, regentkę Niderlandów Marię. Karol V troszcząc się o synową pisał do Filipa, aby zadbał o zdrowie małżonki, a także dopilnował, aby nie pisała własnoręcznie listów, by nie doprowadzić do poronienia ${ }^{53}$.

Kluczową dla pozycji Filipa w Anglii była jego koronacja. Już w listopadzie 1554 r. Simon Renard namawiał Marię, aby przemyślała tę kwestię. Królowa stwierdziła, że będzie musiała rozważyć przedstawienie tej sprawy na forum najbliższego parlamentu ${ }^{54}$. W kolejnych listach ambasador studził jednak swój własny zapał, zauważając, że doprowadzenie do koronacji cesarskiego syna nie będzie tak łatwe. Wynikało to ze szczególnej roli, jaką ceremonia ta ogrywała w Anglii. Jak pisał: tutaj, w Anglii koronacja stanowi prawdziwe i prawomocne potwierdzenie tytułu, i ma o wiele większe znaczenie niż $w$ innych królestwach ${ }^{55}$. Koronacja była szczególnie istotna, gdyż wielu angielskich dostojników wręcz otwarcie twierdziło, że jeżeli cokolwiek złego spotka królową, wówczas władcą zostanie ogłoszony Courtenay, który pojmie za żonę królewnę Elżbietę ${ }^{56}$. Akt namaszczenia podniósłby więc pozycję Filipa, co miałoby niebagatelne znaczenie w przypadku bezdzietnej śmierci jego żony. Sama królowa chętnie przystałaby na koronację ukochanego małżonka, lecz zdawała sobie sprawę z istnienia silnej opozycji w tym zakresie, dlatego też nie nalegała na członków Tajnej Rady. Jednocześnie dbała jednak, aby jej mąż mógł odgrywać jak największą rolę w zarządzaniu państwem. Dlatego też każdy dokument tłumaczono na łacinę lub hiszpański, żeby Habsburg mógł rozumieć, jakie decyzje są podejmowane w Anglii. Król jednak nie rozumiał zasad angielskiego prawa i wolał nie podejmować samodzielnych decyzji dotyczących ojczyzny małżonki, lecz zdawał się na zdanie swych doradców ${ }^{57}$. Mimo to sumiennie uczestniczył we wtorkowych i piąt-

${ }^{51}$ Edwards, op. cit., s. 208.

52 R. McCoy, op. cit., s. 427-430.

${ }^{53}$ Karol V do Filipa Habsburga, październik 1554, CSP, Spain, s. 75-76.

54 Simon Renard do Karola V, 6 listopada 1554, CSP, Spain, s. 77.

55 Simon Renard do Karola V, 23 listopada 1554, CSP, Spain, s. 106-107.

56 Simon Renard do Karola V, 13 marca 1555, CSP, Spain, s. 143-144.

57 D. Loades, Philip II and the..., s. 180-188. 
kowych posiedzeniach Tajnej Rady ${ }^{58}$. Filip, w związku z niedyspozycją, małżonki przejmował na siebie sporą część monarszych obowiązków, na każdym dokumencie wydanym przez Tajną Radę miał widnieć także jego podpis ${ }^{59}$.

Wiosną 1555 r. Habsburg zaczął rozmyślać o opuszczeniu Anglii i udaniu się do Niderlandów. Simon Renard przekonywał go, by tego nie robił, ponieważ jeżeli królowa umrze podczas porodu, wówczas władzę odziedziczyć może Elżbieta, nieobecny zaś Habsburg nie będzie miał na to żadnego wpływu. Poza tym źle w samym królestwie absencja Filipa będzie źle widziana i może zniechęcić wielu spośród pozyskanych już członków Tajnej Rady $^{60}$. Dlatego Habsburg odmówił udania się do Niderlandów, czego oczekiwał od niego Karol $V^{61}$.

Filip zdecydował się więc pozostać w Anglii przynajmniej do czasu narodzin swego potomka. Dziecka Marii oczekiwał nie tylko on, ale także wszyscy członkowie rodu Habsburgów. Sam cesarz musiał zdawać sobie sprawę, że królowa nie jest młoda i być może jest to ostatni moment na urodzenie przez nią zdrowego dziecka. W maju 1555 r. Europę obiegła informacja, że Maria urodziła chłopca. Gratulacje z tej okazji złożyła Filipowi jego siostra ${ }^{62}$. Także w Londynie przedwcześnie świętowano narodziny królewskiego potomka. Na razie jednak para królewska przygotowała jedynie blankiety listów, które miały zostać rozesłane po Europie, gdy tylko narodzi się potomek Marii ${ }^{63}$. Jak się okazało nie były one potrzebne, latem 1555 r. stwierdzono, że królowa w ciąży nie była, zaś jej objawy spowodowane były prawdopodobnie ciążą urojoną. Sprawa ta nadwyrężyła uczucia, jakim król darzył Marię. Ponadto przed dyplomatami angielskimi w całej Europie stanęło trudne zadanie wytłumaczenie całej sytuacji ${ }^{64}$. Bez wątpienia bowiem Habsburgowi zależało na narodzinach potomka, który mógłby objąć tron Anglii i tym samym po raz kolejny poszerzyć granice panowania domu austriackiego.

Mimo rozczarowania król cały czas angażował się w zarządzanie królestwem. Po śmierci jesienią 1555 r. kanclerza Gardinera starał się na opróżnione stanowisko promować Williama Pageta. Na to nie chciała jednak przystać królowa, Filipowi udało się jednak doprowadzić do mianowania

${ }^{58}$ G. Redworth, Matters Impertinent to Women': Male and Female Monarchy under Philip and Mary, „The English Historical Review” 1997, vol. 112, no. 447, s. 601.

59 Ibidem, s. 601.

${ }^{60}$ Simon Renard do Filipa Habsburga, niedatowany list, prawdopodobnie koniec marca lub początek kwietnia 1555 r., CSP, Spain, s. 152-153.

${ }^{61}$ H. Kelsey, op. cit., s. 109-111.

${ }^{62}$ Joanna Habsburżanka do Filipa Habsburga, 17 maja 1555, CSP, Spain, s. 172.

${ }^{63}$ Vide: Calendar of State Papers, Foreign Series, of the Reign of Mary, 1553-1558, red. W. Turnbull, London 1861, (dalej: CSP, FS, Mary I), s. 172-173.

${ }^{64}$ J. Edwards, op. cit., s. 268. 
na stanowisko lorda Tajnej Pieczęci hrabiego Bedford ${ }^{65}$. Ponadto król Anglii chciał usprawnić proces podejmowania decyzji wewnątrz Tajnej Rady. Dlatego też poparł pomysł wysunięty przez Williama Pageta wyodrębnienia spośród tegoż tworu węższego ciała, które miało mieć większe zdolności do szybkiego podejmowania decyzji. Organ ten funkcjonujący pod nazwą Select Council został ustanowiony w $1555 \mathrm{r}^{66} \mathrm{~W}$ jego skład weszło zaledwie dziewięć osób. Mieli oni uprawnienia finansowe, mogli zarządzać królewskimi majątkami, podejmować decyzję dotyczące zaciągania pożyczek. Bez wątpienia ograniczenie grona osób, które mogą podejmować decyzje w najważniejszych sprawach, usprawniło proces zarządzania krajem ${ }^{67}$. Jak więc widać Filip brał udział w podejmowaniu najważniejszych decyzji w zakresie administrowania Anglią.

Kiedy stało się jasne, że królowa nie powije następcy, młody Habsburg podjął decyzję o opuszczeniu ojczyzny żony. Zależało mu na tym, aby udać się do Niderlandów, gdyż chciał przypilnować spraw dotyczących sukcesji. Karol V oficjalnie już zapowiedział swą abdykację, także wieloletnia regentka Niderlandów - królowa Maria, chciała zrezygnować już z pełnionej przez siebie funkcji. Głównym powodem jej zwłoki było oczekiwanie na przybycie Filipa. Wdowa po czeskim i węgierskim królu pragnęła udać się do Hiszpanii i zamieszkać tam razem z siostrą Izabelą ${ }^{68}$. Dlatego też Filip podjął decyzję o opuszczeniu Anglii. Wcześniej jednak przygotował szereg instrukcji dotyczących sprawowania władzy pod jego nieobecność. Dotyczyły one między innymi tego, kto powinien zasiadać w zbliżającym się parlamencie (Habsburg preferował osoby wyznające katolicyzm o nieskazitelnym charakterze). Do tego król radził małżonce, aby uczestniczyła w posiedzeniach Tajnej Rady. Po wydaniu tych dyspozycji pod koniec sierpnia 1555 r., Filip odpłynął z Albionu ${ }^{69}$.

Maria, chociaż rozumiała, dlaczego jej małżonek musiał opuścić Anglię, to niecierpliwie oczekiwała na jego powrót do kraju, czemu wyraz dawała w swych listach do Karola $V^{70}$. Wraz z upływem czasu w korespondencji tej

65 D. Loades, Mary I, s. 142.

${ }^{66}$ Pomysł ten Paget przedstawiał już w początkach panowania Marii, lecz został on wówczas storpedowany przez kanclerza Gardinera. Później angielski lord starał się przekonywać do swojego pomysłu ambasadora Renarda, a nawet cesarza. Jednak dopiero dzięki zaangażowaniu Filipa udało się doprowadzić do jego realizacji; A. Weikel, The Marian Councilrevisited, [w:] The Mid-Tudor Polity c. 1540-1560, ed J. Loach, R. Tittler, London 1985, s. 70-73.

${ }^{67}$ S. Gammon, op. cit., s. 222-223.

${ }^{68}$ Maria Habsburżanka do Karola V, niedatowane, prawdopodobnie sierpień 1555, CSP, Spain, s. 249.

${ }^{69}$ H. Kelsey, op. cit., s. 113-114.

${ }^{70}$ Maria Tudor do Karola V, maj 1556, CSP, Spain, s. 267. 
zaczęła pojawiać się nuta desperacji. Królowa żaliła się teściowi, że Filip nie reaguje na jej wezwania do powrotu do kraju¹. Mąż królowej tymczasem zamiast planować powrót do Albionu, nakazał swojemu dworowi opuszczenie Anglii i dołączenie do niego w Brukseli ${ }^{72}$. We wrześniu 1555 r. przedłużająca się nieobecność władcy zaczęła niepokoić także członków Tajnej Rady, którzy wyrażali nadzieję na rychły powrót króla, aczkolwiek spodziewali się może chcieć udać się on najpierw do Hiszpanii ${ }^{73}$.

Dopiero w lutym 1557 r. Filip zdecydował się wysłać do Anglii swego przedstawiciela, którego głównym zadaniem było zwrócenie królowej uwagi na dwulicowość Francuzów planujących atak w Italii ${ }^{74}$. Wkrótce do Anglii przybył sam Filip, którego jednak zajmowało jednak przygotowywanie wojny z Francją niż zajmowanie się sprawami ojczyzny żony. Jego głównym celem było nakłonienie Anglików do wypowiedzenia wojny Francuzom. Był przekonany, że cel ten osiągnie bez większych przeszkód ${ }^{75}$. Królowa chciała, aby powrót jej męża do Anglii była jak najprzyjemniejszy. Z pomocą Tajnej Rady zadbała o właściwy statek, transport oraz towarzystwo dla długo wyczekiwanego małżonka ${ }^{76}$. Jak się okazało Filip miał rację co do bezproblemowego namówienia ojczyzny żony do wystąpienia przeciwko Francji, gdyż deklaracja wojny 7 czerwca 1557 r. Anglia wypowiedziała jednak Francji wojnę ${ }^{77}$. Był to niewątpliwy sukces Habsburga, któremu potrzebna była angielska flota, którą teraz mógł dysponować ${ }^{78}$. Ponadto do Calais udał się oddział pod wodzą hrabiego Pembroke, który miał wspierać Hiszpanów na lądzie ${ }^{79}$. Przywiódł on ze sobą korpus złożony z 18 tysięcy ludzi. Siły te, aczkolwiek spóźnione, udały się pod Saint Quentin oblegane przez wojska hiszpańskie ${ }^{80}$. Osiągnąwszy główny cel, Filip latem 1557 r. opuścił Albion. Tym razem zostawił jednak swego przedstawiciela Juana de Figueroa, hrabiego Ferię, który miał zadbać o interesy króla podczas jego nieobecności. Ten zaś o sytuacji w Anglii informował nie tylko swego pana, ale także Karola V ${ }^{81}$. Hrabia Feria starał się wypełnić swoje obowiązki jak najlepiej, lecz sam przyznawał, że ma problemu z porozumieniem się z Anglikami. Jak pisał do Filipa:

${ }^{71}$ Maria Tudor do Karola V, 10 września 1556, CSP, Spain, s. 275-276.

72 H. Kelsey, op. cit., s. 117.

${ }^{73}$ APC, vol. 5, s. 184.

${ }^{74}$ Filip Habsburg do Ruy'aGómeza de Silva, 2 lutego 1557, CSP, Spain, s. 285.

75 Filip Habsburg do biskupa Arras, 4 maja 1557, CSP, Spain, s. 291.

${ }^{76}$ APC, vol. 6, s. 56.

77 Deklaracja poczyniona w Londynie 7 czerwca deklarująca wojnę z Francją, 7 czerwca 1557, CSP, Spain, s. 293.

78 Filip Habsburg do Pero Menéndezy, 30 czerwca 1557, CSP, Spain, s. 299.

79 Hrabia Pembroke do Filipa Habsburga, 19 lipca 1557, CSP, Spain, s. 304.

${ }^{80}$ L. Porter, op. cit., s. 440.

${ }^{81}$ Juan de Figueroa do Karola V, 15 sierpnia 1557, CSP, Spain, s. 316-317. 
Klnę się na Boga, nie jestem w stanie zrobić tutaj nic więcej, jak też nie wiem, co zrobić z tymi ludźmi. Wasza Wysokość rozumie, że oni zmieniają swe zdanie nim upłynie okres od nocy do rana i ponownie nim upłynie czas od dnia do nocy, i nie ma żadnego sposobu, by ich zrozumieć [...]. Królowa, nasza pani, mówi, że robi wszystko co może, i zaprawdę ma ona chęć i dobrą wolę do wykonania najpotrzebniejszych prac $^{82}$.

Mimo swojej nieobecności w kraju Filip miał wpływ na kształt polityki zagranicznej prowadzonej przez Anglię. To on wstępnie zgodził się na układy handlowe zawarte między Albionem a Danią i miastami hanzeatyckimi, którą to uzasadniał dobrymi relacjami tych państw zarówno z Anglią jak i Niderlandami ${ }^{83}$. Wciąż jednak król nie wyrażał ostatecznej zgody na podpisanie traktatów. Niecierpliwiący się Anglicy poinformowali króla, że Anglia od bardzo dawna utrzymuje kontakty z miastami należącymi do Hanzy i obecne negocjacje mają na celu jedynie pewną zmianę warunków ${ }^{84}$. Do tego Habsburg zaangażował się w rozwiązanie konfliktu szkocko-angielskiego. Od 1557 r. na granicy państw brytyjskich dochodziło do starć. Dlatego też Filip wysłał tam wysłannika pochodzącego z Niderlandów, który miał pomóc rozwiązać konflikt. Szkocja była związana dość silnymi więzami gospodarczymi z Niderlandami, dlatego też syn Karola V sądził, że osoba o takim pochodzeniu może pomóc w rozwiązaniu konfliktu ${ }^{85}$. Na marginesie warto zaznaczyć, że król Danii Chrystian III jeden z listów dotyczących kwestii majątkowych zaadresował tylko i wyłącznie do Filipa ${ }^{86}$. Wszystkie podane powyżej przykłady pokazują, że Habsburg odgrywał dużą rolę w kształtowaniu angielskiej polityki zagranicznej.

Ponadto Filip doprowadził do tego, by na podległych mu terenach Anglicy utrzymali swoje prawa do organizowania jarmarków oraz inne przywileje. Ambasador angielski rezydujący w Brukseli był zdania, że tylko dzięki dobrej woli Filipa Anglicy wciąż mogą cieszyć się tymi uprawnieniami ${ }^{87}$. Do tego deklarował chęć okazania pomocy angielskim kupcom pragnącym robić interesy w Portugaliii8.

Największą jednak rolę król odgrywał w toczących się działaniach wojennych na froncie francuskim. To do Filipa zwracali się dowódcy działający na terenie Francji. To również jego o pomoc prosił gubernator Calais Thomas

${ }^{82}$ Cyt. za J. Edwards, op. cit., s. 316.

${ }^{83}$ Filip Habsburg do Juana de Figueroa, 26 lutego 1558, CSP, Spain, s. 364.

${ }^{84}$ Tajna Rada do Filipa Habsburga, 17 maja 1558, CSP, Spain, s. 381-382.

85 A. Blakeway, The Anglo-Scottish War of 1558 and the Scottish Reformation, „The Journal of Historical Association" 2017, vol. 102, no. 350, s. 206.

${ }^{86}$ Chrystian III do króla Filipa, 23 maja 1555, CSP, FS, Mary I, s. 168.

87 John Masone do Marii I, 8 października 1555, CSP, FS, Mary I, s. 189.

${ }^{88}$ John Masone do Tajnej Rady, 17 grudnia 1555, CSP, FS, Mary I, s. 198. 
Wentworth, gdy pod koniec grudnia pod mury ostatniego skrawka angielskiej ziemi na kontynencie podeszli Francuzi. Miasta nie udało się obronić i Calais zostało stracone 7 stycznia 1558 r. Filip o porażkę obwiniał nieprzygotowanie obrońców miasta, sam usprawiedliwiał się przed Tajną Radą nie upatrując w porażce swej winy ${ }^{89}$. Kiedy wiosną 1558 r. rozpoczęły się negocjacje pokojowe w Ceteau Cambresis przedstawiciele Habsburga pamiętali o angielskich interesach i starali się doprowadzić do tego, aby Calais ponownie znalazło się pod angielskim władaniem ${ }^{90}$.

Rok 1558 i pogorszenie się stanu zdrowia królowej przysporzył Filipowi obaw o sukcesję w Anglii w sytuacji bezpotomnej śmierci Marii. Na jego życzenie raport w tej sprawie sporządził Simon Renard. Wynikało z niego, iż w razie, gdy władczyni nie doczeka się potomka, na tronie zasiądzie jej siostra Elżbieta - protestantka i zwolenniczka Francuzów ${ }^{91}$. Monarchini coraz częściej cierpiała z powodu złego samopoczucia, co prowadziło do opóźnienia w załatwianiu spraw państwowych ${ }^{92}$. Jasnym było też, że królowa nie jest w ciąży. Zdaniem historyków Maria mogła cierpieć na urojoną ciążę, lub też jej objawy powiązane były z zaawansowanym stadium choroby nowotworowej ${ }^{93}$. W związku z tym Filip zdawał sobie z wagi doprowadzenia do korzystnego dla jego interesów księżniczki Elżbiety. Kandydat zaś pojawił się już w kwietniu 1558 r. w osobie syna króla Szwecji Gustawa Wazy - Eryka. Na pomysł takiego mariażu wpadł sekretarz Gustawa Marten Helsing, który przebywał w Anglii do 1557 r. Swym konceptem zaraził władcę, który w 1558 r. wysłał na angielski dwór specjalnego wysłannika w osobie Dionysiusa Beurreusa ${ }^{94}$. Maria w kwestii ewentualnego ożenku młodszej siostry chciała znać zdanie męża, bez jego zgody nie zamierzała najwidoczniej doprowadzić do zawarcia tegoż małżeństwa. Plany te nie miały jednak dalszego ciągu wobec sprzeciwu Elżbiety, która stwierdziła, że za mąż nie wyjdzie ${ }^{95}$.

Szwedzi chcieli przy okazji swej wizyty w Anglii chcieli także doprowadzić do podpisania układu handlowego między oboma krajami. Filip stwierdzał jednak, że warunki zaproponowane przez Skandynawów są nie akceptowalne i w takiej formie Anglia traktatu podpisać nie moż ${ }^{96}$. Można

89 Filip Habsburg do Tajnej Rady, 21 stycznia 1558, CSP, Spain, s. 340.

90 Komisja pokojowa do Filipa Habsburga, 26 i 27 października 1558, CSP, Spain, s. 420-425.

91 Raport sporządzony przez Simona Renarda dotyczący sukcesji w Anglii, marzec 1558, CSP, Spain, s. 370-371.

${ }_{92}$ Hrabia Feria do Filipa Habsburga, 1 maja 1558, CSP, Spain, s. 378.

93 D. Loades, Mary Tudor, London 1996, s. 301-302.

${ }^{94}$ L. Wolke, Jan III Waza. Władca renesansowy, Gdańsk 2011, s. 54-55.

${ }^{95}$ Hrabia Feria do Filipa Habsburga, 1 maja 1558, CSP, Spain, s. 378.

${ }^{96}$ Filip Habsburg do Tajnej Rady, 7 maja 1558, CSP, Spain, s. 380. 
zauważyć, że Filip odgrywał bardzo dużą rolę również w kształtowaniu polityki gospodarczej Anglii. W niemal każdym jego liście kierowanym do hrabiego Ferii z pierwszej połowy 1558 r. pojawia się kwestia handlu wełną. Po utracie Calais Anglicy musieli bowiem znaleźć nowy port, w którym mogliby przechowywać transportowaną na kontynent wełnę. W rozwiązanie tego problemu Filip był głęboko zaangażowany. Proponował Anglikom, aby wełnę przewozić do portów w Dunkierce czy też Antwerpii. Nie wszystkie jego propozycje spotykały się jednak ze zrozumieniem zainteresowanych. Mieszanie się Filipa do negocjacji z Hanzą doprowadziło bowiem do tego, że mimo wielu miesięcy negocjacji nie udało się zawrzeć porozumienia. W związku $\mathrm{z}$ tym rozmowami zainteresował się nawet biskup Arras ${ }^{97}$.

Filip tymczasem zdawał sobie sprawę z pogarszającego się stanu zdrowia żony i dlatego przygotowywał grunt na sytuację, jaka nastąpi po jej śmierci. Polecił swemu ambasadorowi, aby złożył wizytę królewnie Elżbiecie. Był też bardzo ciekaw wyniku rozmów między dyplomatą a młodszą córką Henryka VIII ${ }^{98}$. Kiedy zaś jesienią doszła do niego wiadomość o chorobie małżonki wysłał do Anglii specjalnego wysłannika, który miał zadbać o jego interesy ${ }^{99}$. Napisał także list do lekarzy królowej, w którym dziękował im za podejmowany wysiłek i zachęcał do dalszych starań o przywrócenie Marii zdrowia ${ }^{100}$. Mimo tak dużych wyrazów troski o zdrowie małżonki, nie zamierzał dać jej tego, o czym najbardziej marzyła, czyli swojej obecności. Jesień 1558 r. nie była łaskawa dla Filipa, w krótkim odstępie czasu zmarł jego ojciec, a wkrótce potem ciotka - królowa Maria. Teraz zaś Habsburg musiał zmierzyć się z kolejnym problemem, jakim była ciężka choroba żony. W liście do swej siostry Joanny zwierzał się, że zdaje sobie sprawę z tego, że powinien udać się do Anglii, aby zadbać o własne interesy na wypadek śmierci małżonki ${ }^{101}$.

Ze stanu zdrowia swej pani doskonale zdawali sobie sprawę także członkowie Tajnej Rady, którzy namawiali Marię, aby ogłosiła Elżbietę swą następczynią. Królowa nie chciała tego uczynić, pamiętając o wcześniejszym zdradzieckim zachowaniu córki Anny Boleyn a także jej wyznaniu. Ambasador Feria również dostrzegał rosnącą pozycję Elżbiety i dlatego, zgodnie z wcześniejszymi rozkazami swego pana, składał jej wizyty, w trakcie których przekonywał o jak najlepszych intencjach Filipa. Zainteresowanie Hiszpanów młodszą siostrą królowej nie podobało się wiernej dwórce monarchini,

\footnotetext{
${ }_{97}$ Biskup Arras do Filipa Habsburga, 16 września 1558, CSP, Spain, s. 407.

${ }_{98}$ Filip Habsburg do hrabiego Ferii, 27 maja 1558, CSP, Spain, s. 390.

${ }_{99}$ Filip Habsburg do Tajnej Rady, 22 października 1558, CSP, Spain, s. 416.

100 Filip Habsburg do lekarzy Marii, 22 października 1558, CSP, Spain, s. 417.

101 Filip Habsburg do Joanny Habsburżanki, 4 grudnia 1558, CSP, Spain, s. 439.
} 
Jane Dormer, która zarzucała królowi, iż faworyzuje królewnę ${ }^{102}$. Faktycznie Filip starał się nie zrażać do siebie Elżbiety. Wiosną 1556 r., kiedy posądzano ją o udział w spisku Henry'ego Dudley'a ${ }^{103}$, to właśnie Habsburg przekonał królową do niearesztowania królewny. Mąż Marii nie dbał o dobro swej szwagierki ze względu na jej osobisty urok, lecz dlatego, iż miał co do niej plany. Pragnął, żeby poślubiła ona księcia Sabaudii, wówczas okupowanej przez Francję, Emanuela Filiberta. Kiedy po raz drugi przybył do Anglii wraz z przyrodnią siostrą Małgorzatą Parmeńską oraz kuzynką Krystyną, przekonywali królewnę do jego kandydatury. Ponadto Albion odwiedził sam zainteresowany ręką Elżbiety. Córka Henryka VIII nie chciała jednak wyrazić zgody na ten mariaż, który, słusznie zresztą, uważała za mało atrakcyjny ${ }^{104}$. Jak jednak widać Habsburg nie zaczął okazywać sympatii Elżbiecie dopiero, gdy jego żona stała nad grobem, lecz od początku swojego pobytu w Anglii traktował ją jako istotny element układanki mającej zwiększyć wpływy domu austriackiego na wyspach.

Tymczasem jesienią 1558 r. stan zdrowia królowej nie poprawiał się. $\mathrm{Na}$ początku listopada królowa wreszcie wyznaczyła Elżbietę swą następczynią. W skierowanym do niej liście zaklinała siostrę, aby ta utrzymała w Anglii wyznanie katolickie. 06 rano, 17 listopada Maria wstała, by wysłuchać mszy świętej. Jak się okazało był to ostatni sakrament, w jakim uczestniczyła, bowiem już o 7 rano stwierdzono, iż władczyni umarła. Jej śmierć nie była powodem wybuchu walk o tron. Elżbieta bez problemu zasiadła na tronie. Nie powiódł się tym samym plan Karola V, który na tronie Albionu widział swe wnuki. Bezdzietność Marii zaprzepaściła wszystkie dalekosiężne plany.

Bez wątpienia Filipa Habsburga można nazwać królem Anglii. Tytuł ten przysługiwał mu formalnie, pod nim występował w ojczyźnie żony. Nie ulega wątpliwości także jego zaangażowanie w angielskie interesy. W trakcie pobytu w królestwie małżonki aktywnie angażował się w wewnętrzne sprawy Albionu. Starał się nawiązać jak najlepsze relacje z lordami, a nawet budować podstawy swojego stronnictwa, poprzez promowanie wiernych sobie ludzi na ważne urzędy. Starania te nie zawsze odnosiły skutek, lecz nikt

102 The life of Jane Dormer, Duchess of Feria, red. H. Clifford, London 1887, s. 88.

103 Spisek ten został zawiązany przez kuzyna księcia Northumberland - Henry'ego Dudle'a oraz lordów niezadowolonych z panowania Marii lordów, w tym Richarda Uvedale czy Thomasa Throckmortona. Dudley, który przebywał we Francji miał, dzięki pomocy tamtejszych władz przybić do Anglii z siłami powstańczymi. Plan nie został jednak zrealizowany ze względu na toczące się w 1556 r. negocjacje między Francją a Habsburgami. Rząd Henryka II odmówił wsparcia buntowników, jednak mimo to wieści o ich zamiarach dotarły do członków Rady. 0 zamierzeniach wszczęcia powstania przeciwko królowej na bieżąco informowano księżniczkę Elżbietę; L. Porter, op. cit., s. 432-433.

104 J. Edwards, op. cit., s. 323-324. 
nie kwestionował zaangażowania Habsburga w administrowanie Anglią. Przez okoliczności związane z przejęciem władzy po ojcu Filip nie mógł na stałe przebywać na wyspach, lecz przez większą część panowania swej żony przebywał w Niderlandach. Nawet tam angażował się jednak w sprawowanie władzy w kraju, którego władcą został poprzez małżeństwo. Jego uwaga szczególnie koncentrowała się na polityce zagranicznej i handlu międzynarodowym. Najwięcej kontrowersji budzi udział Anglii w wojnie z Francją, która skończyła się dla tej pierwszej utratą Calais. Bez wątpienia to Filip dążył do tego, aby ojczyzna jego żony wypowiedziała wojnę krajowi, z którym Habsburg był w konflikcie. Należy jednak zaznaczyć, iż Anglicy od początku panowania Marii pozostawali w napiętych relacjach z Francuzami ${ }^{105}$. Syn Karola $V$ po utracie ostatniego angielskiego przylądka pamiętał o nim w negocjacjach pokojowych i dążył do restytucji miasta do Anglii. Krótki okres sprawowania rządów nie pozwolił mu jednak na umocnienie pozycji. Brak koronacji oraz potomstwa z Marią sprawiły, że po 1558 r. umarła nadzieja na utworzenie angielskiej linii Habsburgów.

\section{BIBLIOGRAFIA}

\section{Źródła}

Acts of the Privy Council of England, ed. J. Roche, vol. 5-6, London 1896.

Calendar of State Papers, Foreign Series, of the Reign of Mary, 1553-1558, ed. W. Turnbull, London 1861.

Calendar of State Papers, Spain, vol. 11-13, ed. M. Hume, R. Tyler, London 1916-1954.

English Economic History. Select Documents, eds A. Bland, P. Brown, R. Tawney, London 1914. The life of Jane Dormer, Duchess of Feria, ed. H. Clifford, London 1887.

Select Documents of English Constitutional History, red. G.B. Adams, H.M. Stephens, New York 1914.

The statutes of the realm, vol. 3, part. 1, London 1819.

\section{Opracowania}

Blakeway A., The Anglo-Scottish War of 1558 and the Scottish Reformation, „The Journal of Historical Association" 2017, vol. 102, no. 350.

Boyden J., The Courtier and the King Ruy Gómez De Silva, Philip II, and the Court of Spain, California 1995.

105 Vide: E. Harbison, French Intrigueat the Court of Quuen Mary, „The American Historical Review" 1940, vol. 45, no. 3. 
Edwards J., Mary I: England's Catholic Queen, Yale 2011.

Gammon S., Statesman and schemer. William, first lord of Paget - Tudor minister, Newton Abbot 1973.

Harbison E., French Intrigue at the Court of Quuen Mary, „The American Historical Review” 1940, vol. 45, no. 3 .

Hogrefe P., Legal Rights of Tudor Women and the Circumvention by Men and Women, „The Sixteenth Century Journal" 1972, vol. 3, no. 1.

Kelsey H., Philip of Spain. King of England: the forgotten sovereign, London 2012.

Kubiaczyk F., Cesarz Karol V. Klęska polityki, triumf idei, Oświęcim 2017.

Loades D., Mary Tudor, London 1996.

Loades D., Philip II and the Goverment of England, [w:] Law and Govermentuder the Tudors, ed. by Claire Cross, Loades D.M., Scarisbrick J.J., Cambridge 1988.

Masello S., A Booke of the Travaile and Lief of Me Thomas Hoby, with Diverse Thinges Woorth the Notinge, 1547-1564: A Modern Edition with Introduction and Notes, Chicago 1979, http://ecommons.luc.edu/luc_diss/1865, dostęp: 8.05.2018.

McCoy R., From the Tower to the Tiltyard: Robert Dudley's Return to Glory, „Historical Journal” 1984, vol. 27, no. 2.

Redworth G., Matters Impertiment to Women': Male and Femaleunder: Phillip and Mary, „, The English Historical Review" 1997, vol. 112, no. 447.

Redworth G., Philip I of England, Embezzlement, and the QuantityTheory of Money, „The Economic History Review" 2002, vol. 55, no. 2.

Richards J.M., Mary Tudor as „sole Queene”?: gendering Tudor monarchy, „The Historical Journal" 1997, vol. 40, no. 4.

Rodríguez-Salgado M., The Changing Face of Empire: Charles V, Philip II and Habsburg Authority, 1551-1559, Cambridge 1988.

Samson A., Changing Places: The Marriage and Royal Entry of Philip, Prince of Austria, and Mary Tudor, July-August 1554, „The Sixteenth Century Journal” 2005, vol. 36, no. 3.

Samson A., The marriage of Philip of Habsburg and Mary Tudor and anti-Spanish sentiment in England: political economies and culture, 1553-1557, London 1999, (rozprawa doktorska), https://qmro.qmul.ac.uk/xmlui/handle/123456789/1604, dostęp: 18.05.2018.

Sanchez M.G., Anti-Spanish sentiment in English literary and politicalwriting 1553-1603, Leed 2004, (rozprawa doktorska), http://etheses.whiterose.ac.uk/392/1/uk_bl_ethos_ 414874.pdf, dostęp: 18.05.2018.

Parker G., Filip II, Warszawa 1985.

Pfandl L., Philipp II. - Gemäldeeines Lebensundeiner Zeit, Hamburg 2013.

Porter L., Maria Tudor, Kraków 2013.

Taylor J., The shadow of the whiterose. Edward Courtenay earl of Devon. 1526-1556, New York 2006.

Weikel A., The Marian Council Revisited, [w:] The Mid-Tudor Polity c. 1540-1560, ed J. Loach, R. Tittler, London 1985.

Wolke L., Jan III Waza. Władca renesansowy, Gdańsk 2011.

Wurzbach von C., Habsburg, Johanna von Oesterreich (Gemalin Johann's), [w:] Biographisches Lexikon des Kaiserthums Oesterreich, Teil 6, Wien 1860. 
Magdalena Makówka

\title{
HABSBURG ON THE THRONE OF ENGLAND. THE POSITION OF PHILIP HABSBURG IN ENGLAND FROM 1554 TO 1558
}

\begin{abstract}
$\mathrm{T}$ he wedding of Philip of Spain and Mary I of England was a cause of a major controversy. There was a fearthat the Queen's marriage with the Habsburg could possibly be a reason for many threats to the English independence. In this case the highly specific provisions regarding the Philip's power concluded during the marriage are not surprising. While him being in England, Philip was displaying an interest in the English domestic policy and was actively participating in the administering of the country. Moreover, his actions leaded to England taking part in the war with France resulting in losing of Calais by the Philip's wife homeland. Childless death of the Queen was the reason why the Habsburg had lost all of his English influences.
\end{abstract}

Keywords: Philipp Habsburg, Mary I, power, England. 